\title{
Forest Management in the State of Amapá, Brazil
}

\author{
José das Dores de Sá Rocha ${ }^{1}$, José de Arimatéa Silva², Vitor Afonso Hoeflich ${ }^{3}$, \\ Anadalvo Juazeiro dos Santos ${ }^{3}$, Claudio Luchesa ${ }^{4}$ \\ ${ }^{1}$ Universidade Federal de Rondônia - UNIR, Rolim de Moura/RO, Brasil \\ ${ }^{2}$ Universidade Federal Rural do Rio de Janeiro - UFRRJ, Seropédica/RJ, Brasil \\ ${ }^{3}$ Universidade Federal do Paraná - UFPR, Curitiba/PR, Brasil \\ ${ }^{4}$ Centro Universitário Curitiba - UNICURITIBA, Curitiba/PR, Brasil
}

\begin{abstract}
This study aims to show the organizational capacity and structure of the forest management system of the State of Amapá, Brazil. The research was based on the principles applied in Public Administration functions. We found that forest management in Amapá is performed by four State agencies consisting of two management systems that act on the production side, with one being in direct administration as the formulator of forestry policy, and one being an autonomous agency linked to the previous one as executor of forestry policy, and the other two systems being more directly linked to protection, with one being a formulator of environmental policy and the other its executor. There was a statistically significant correlation between the perceptions of public officers and the users of institutions regarding the organizational system. Some conflicts were observed between the four institutions in terms of forest administration responsibilities. We concluded that the maintenance of the existing forest coverage is not directly due to institutional capacities.
\end{abstract}

Keywords: governance, organizational management, Amazon. 


\section{INTRODUCTION}

Changes in global forest coverage are largely the result of human action directed towards meeting some desire or need, such as food, fuel, or profit, as evidenced by the World Resources Institute, Imazon, and ICV (WRI et al., 2009). Therefore, direct and indirect impacts generated by the public policy of other sectors such as energy, agriculture, and others affect forests and, consequently, the local ecosystem and socioeconomics (FAO, 2002, 2010, 2005). In this respect, Nepstad et al. (2014) indicates that the types of policies drafted for agriculture, livestock, infrastructure, market structure, regulatory agencies, credit, and legal frameworks are the main factors that condition deforestation in Legal Amazon, along with mining and energy.

The devastation and degradation of forestry resources are mainly due to human consumption demands and desires, including processes involved in these actions and, ultimately, are the result of the policies adopted by countries and states and their institutional capacities (Becker, 2001, 2009, 2011; Costa \& Costa, 2009; Tucker \& Ostrom, 2009).

Despite the loss of forest coverage in the Brazilian Amazon biome, which has approximately $18.4 \%$ of its original coverage, the State of Amapá showed the least loss of forest coverage in the region - approximately $1.4 \%$ of the 142,800 square kilometers of the area (INPE, 2014; Pereira et al., 2010). However, there is evidence of forest coverage maintenance in some states of the Amazon region. As in Amapá, this maintenance is not a direct result of conservation policies and the proper functioning of its institutions, but is due to other geographic and economic factors (Becker, 2001; IBGE, 2014).

For Tucker \& Ostrom (2009), the main problem faced by forest institutions is the degree to which they can effectively fulfill their roles in the management of forest resources given the diverse and conflicting interests.

Coordination of the use and protection of the vast forest coverage - which is still present in Amapá - is the main challenge faced by institutions, because of the increasing pressures owing to alternative uses of soil and land and the need to manage these resources to improve the quality of life of the population. In this sense, we assume that one of the main problems present in this process is the fragility of the management capacities of institutions. Thus, this study aims to elucidate the structures and capacities of organizational processes aimed at managing the use and protection of forests in the State of Amapá, Brazil.

\section{METHODOLOGY}

This study focused on the state system responsible for managing forestry resources in the State of Amapá, represented by the Institute of Environment and Territorial Planning of the State of Amapá (IMAP), the State Environment Department (SEMA), the State Forest Institute (IEF), and the State Department of Rural Development (SDR) (Figure 1).

This research sought to typify the state system of forest management based on the organizational structures and functions established by the state public authority, which include the: a) organizational model, institutional attributions, and legal nature of forestry resources and b) forest management.

The data and information regarding the legal nature, attributions, and organizational models were collected along with the actions of the state public power - laws, decrees, and technical documents.

Regarding organizational management, we used a standard questionnaire, which allowed us to obtain an overview of the State about forests, as well as the peculiarities of forest management from the perception of users and public officers. This research instrument was elaborated in light of the elements of public management referenced by Lima (2007) and, after having been adapted, it corresponded to: a) Forest planning, b) Implementation (forest management structure,



Figure 1. State system of forest management. State of Amapá, represented by the Institute of Environment and Territorial Planning of the State of Amapá (IMAP), the State Environment Department (SEMA), the State Forest Institute (IEF), and the State Department of Rural Development (SDR). 
administrative processes, and human resources), c) Control (service and public service, governance, and social interaction), and d) Organizational management and standardization.

The questionnaire was applied with all public agents participating in the construction process of the State Forest Program of Amapá (PEF/AP), which corresponds to a census of thirty-five answered questionnaires. Regarding organizational management, we compared the perceptions of public officers with the users of the State System of Forest Management using the Spearman correlation method with a significance level of $1 \%$ probability. The statistical analysis of the similarity of preference of alternatives for organizational management between the two audiences was performed using the program R Core Team (2013).

We analyzed the forest management based on the conversion of the answers of the questionnaires, which were adapted qualitatively and quantitatively, using the Likert scale - used in this type of research by Bernâsen \& Machado (1974), Saraph et al. (1989), Cunha (2007), and Luchesa (2013). The correlation test proposed by Spearman, according to Siegel (1975) and Luchesa (2013), was applied for this data and the following formula: $\mathrm{r}_{\mathrm{sp}}=1-\left\{6 \cdot \sum \mathrm{d}^{2} / \mathrm{n} .\left(\mathrm{n}^{2}-1\right)\right\}$ was used.

The Spearman correlation coefficient - which ranges from -1 to +1 (the closer to +1 , the greater the correlation between two opinions while the negative value represented the opposite) - determines the degree of similarity of the preferences of respondents - users and officers of the forest management system - regarding planning, implementation, and control of forest management.

\section{RESULTS AND DISCUSSION}

\subsection{Institutions responsible for forest management}

In order to put into practice the set of responsibilities of the state established by the Federal Constitution of 1988, in relation to forestry resources, the State Environmental System (SIEMA) was created in 1994, by Law 165 of 18/1994, which aims to enforce the state environmental policy. The State Environment Department (SEMA), the executive agency of this policy, was subsequently created. The SEMA had its origins in the State Environmental Coordination -
CEMA, created by Decree 11, of May 12, 1989, being regulated by Decree No. 304, from December 18, 1991 -, which had as its objective to guide the environmental policy of the State of Amapá. The first environmental agency of the state was extinguished with the creation of the Department.

The SEMA is the formulator of environmental policy and the Institute of Environment and Territorial Planning of the State of Amapá (IMAP) is the executor of this policy and territorial planning.

Regarding production, forest resources come from the State Department of Rural Development (SDR), which numbers among its responsibilities the formulation and coordination of forestry and extractive policy - from Law 1073, of April 2, 2007. On this same date, Law 1,077 was enacted, which created the State Forest Institute of Amapá (IEF), an autonomous agency linked to SDR that is responsible for ensuring the execution of the state forestry policy. The institutions related to the coordination of the use and protection of forestry resources received their latest alterations and attributions with this same law.

Below, we present the institutions and their functions, respectively:

\section{- SEMA}

o To formulate and coordinate the environment, land, and territorial planning policies of the State of Amapá.

\section{- SDR}

o To formulate and coordinate the state policies for agriculture, livestock, aquaculture, fishery, forestry, extraction, agribusiness and supply, defense, and animal and plant oversight.

\section{- IEF}

o To implement the forestry policy of the State of Amapá in agreement with the macro policies for State development.

\section{- IMAP}

o To execute the policies for environment, territorial space management, and natural resources of the State of Amapá and to exercise other related duties such as regulation.

Therefore, the organizational model responsible for the formulation and implementation of the forestry policy of Amapá is arranged in four institutions, with 
two involving direct administration and two involving indirect administration.

However, there is a division of forest management in Amapá between these four institutions, covering areas of environment, land management, land tenure, and rural development. This distribution of attributions overlaps the roles of the institutions and leads to questionable outcomes in terms of the efficiency of their management practices, because of the distribution of responsibilities that are interrelated between forest lands, conservation units, and rural and forest production.

\subsection{Organizational management for forests in Amapá}

Firstly, we performed a general analysis of the elements that constitute organizational management, from the perspective of the public officers of the institutions that comprise the state system for forest management and the users of these institutions. Then, we proceeded with the detailed analysis of the state forest management system, in four respects: forest planning, implementation, control system, and organizational management and standardization.

Table 1 presents the results of the statistical analysis used to verify the level of agreement between the perception of the public officers and the users of the state system of forest management. The value reveals

Table 1. Statistical analysis of elements of organizational management, and the perspective of public officers and users of the State System of Forest Management.

\begin{tabular}{|c|c|c|}
\hline Items & $\begin{array}{l}\text { Correlation } \\
\text { coefficient } \\
\text { (r) }\end{array}$ & p-value ${ }^{\star}$ \\
\hline Forestry planning & 0.7678 & $<0.001$ \\
\hline $\begin{array}{l}\text { Forest management } \\
\text { structure }\end{array}$ & 0.8546 & $<0.001$ \\
\hline Human resources & 0.6645 & $<0.001$ \\
\hline $\begin{array}{l}\text { Administrative processes } \\
\text { and structure }\end{array}$ & 0.7686 & $<0.001$ \\
\hline Information system & 0.7472 & $<0.001$ \\
\hline $\begin{array}{l}\text { Provision of service and } \\
\text { citizen services }\end{array}$ & 0.7702 & $<0.001$ \\
\hline Governance networks & 0.7491 & $<0.001$ \\
\hline $\begin{array}{l}\text { Organizational management } \\
\text { and standardization and } \\
\text { control }\end{array}$ & 0.7853 & $<0.001$ \\
\hline
\end{tabular}

${ }^{*} \mathrm{p}=$ level of significance; $\mathrm{r}=$ correlation coefficient. the degree of similarity regarding the preferences of respondents for each management aspect. When positive, there is agreement between the two samples at the level of pre-established significance.

We found correlations between the perceptions of users and public officers for all elements of organizational management analyzed - variables of planning, execution, control, and management and standardization. This result indicates that all actors involved in forest management - users and public officers of state institutions alike -, agree regarding the level of deficiency or capability of the State System of Forestry Management. The lowest correlation was obtained for the item "human resources", with a value greater than 0.6 (the closer to 1 , the greater the correlation).

\subsubsection{Forestry planning}

This item addresses the study of the planning structure and strategies of the State for the use and protection of forestry resources over the short, medium, and long terms, from the perspective of the technicians in charge of management and the users of the state system involved in the forestry sector.

The items on the questionnaires aim to ascertain considerations about the implementation of planning, in agreement with the institutional mission of meeting social demands. Forestry planning also includes the planning system sector, civil participation, integration with general state planning, and policy and institutional performance indicators.

The results point to a relative confluence of perceptions between public officers of the institutions responsible for forest management and their users, with averages concentrated in the same evaluation brackets and with little difference regarding the state planning system for the use and protection of forestry resources. The answers were grouped between reasonable and poor evaluations, which serves as an indicator for public managers regarding the degree of weakness of the state apparatus in fulfilling its role, within the ambit of the coordination of planning related to forestry resources (Table 1).

The Spearman correlation coefficient was $r_{p s}=0.77$. According to Luchesa (2013), the closer to 1, the higher the correlation, indicating a correlation between the perception of public officers and users of the State 
System of Forest Management regarding state forestry policy and planning until the research.

The first element of this research, which addresses the state forestry policy in effect at the time of completing the questionnaire, already demonstrates the need to develop the study in the view of officers and users, according to the concentration of responses between reasonable and poor. The same pattern was observed for the other essential elements for the functioning of the state apparatus, necessary for planning (Table 2). This result, presented in Tables 1 and 2, reveals the deficiency of the institutional system, in all elements required for the proper functioning of the state structure when planning and implementing policy for the use and protection of forestry resources. This reflects the low participation of forestry activity in socioeconomics, in a state that has $95 \%$ of its territory covered by forests.
As Husch (1987) and Tucker \& Ostrom (2009) demonstrated, the institutional deficiency identified in the research may contribute to the low capacity for arbitration of conflicts of interests between different social parties, producers, and consumers in the use and protection of forestry resources.

Based on the results presented, we can see the demand in the state for structuring and strengthening the state system of forest planning in order to respond to social expectations, fulfilling its role as coordinator of the use and protection of forestry resources, as outlined by the Constitution.

\subsubsection{Implementation}

This aspect seeks to gain information about the implementation capacity and preparation of what was planned. It also evaluates the capacity of the organizational, physical, and instrumental structure, based on legal

Table 2. Results of the evaluation on forest policy and planning, from the perspective of public officers and users of the system.

\begin{tabular}{|c|c|c|c|c|c|c|c|c|c|c|}
\hline \multirow{3}{*}{ Forestry planning } & \multicolumn{10}{|c|}{ Situation (\%) } \\
\hline & \multicolumn{5}{|c|}{ Public officers } & \multicolumn{5}{|c|}{ Users } \\
\hline & $\mathbf{A}^{*}$ & $\mathbf{B}^{*}$ & $\mathbf{C}^{*}$ & $\mathbf{D}^{*}$ & $\mathbf{E}^{*}$ & A & B & C & D & $\mathbf{E}$ \\
\hline State Forestry Policy & & & 19 & 38 & 43 & & & 29 & 14 & 57 \\
\hline $\begin{array}{l}\text { Instruments for the implementation and } \\
\text { execution of forestry policy }\end{array}$ & & & 19 & 48 & 33 & & & 29 & 29 & 43 \\
\hline $\begin{array}{l}\text { Integration between formulation and } \\
\text { implementation of forest policy }\end{array}$ & & & 14 & 43 & 43 & & & 29 & 14 & 57 \\
\hline $\begin{array}{l}\text { Mechanisms of social participation in forestry } \\
\text { policy and planning }\end{array}$ & & & 14 & 33 & 52 & & & & 29 & 71 \\
\hline $\begin{array}{l}\text { Integration between budget, planning, and } \\
\text { evaluation of the agency }\end{array}$ & & & 14 & 43 & 43 & & & & 57 & 43 \\
\hline Integration between PPA and forest policy & & & 19 & 43 & 38 & & & & 57 & 43 \\
\hline $\begin{array}{l}\text { Participation of the Agency in the general } \\
\text { planning of the State }\end{array}$ & & 5 & 33 & 33 & 29 & & & 14 & 57 & 29 \\
\hline $\begin{array}{l}\text { Relevance of the forest component in } \\
\text { institutional planning }\end{array}$ & 5 & & 33 & 38 & 24 & & & & 43 & 57 \\
\hline $\begin{array}{l}\text { Integration of forest policy guidelines and } \\
\text { institutional planning }\end{array}$ & & & 29 & 29 & 43 & & & & 57 & 43 \\
\hline $\begin{array}{l}\text { Internalization of the PPA in the } \\
\text { Environmental and Forestry Agency }\end{array}$ & & 5 & 5 & 43 & 48 & & & & 71 & 29 \\
\hline Adoption of strategic planning in the Agency & & 5 & 14 & 29 & 52 & & & 29 & 14 & 57 \\
\hline $\begin{array}{l}\text { Qualification of human resources in the area of } \\
\text { forestry policy and planning }\end{array}$ & & & 29 & 43 & 29 & & & 29 & 43 & 29 \\
\hline Institutional performance indicators & & & 5 & 33 & 62 & & & & 43 & 57 \\
\hline Budget management & & 5 & 10 & 43 & 43 & & & 14 & 57 & 29 \\
\hline Planning system & & 5 & 14 & 43 & 38 & & & 14 & 57 & 29 \\
\hline Average & & 2 & 18 & 39 & 41 & & & 12 & 43 & 45 \\
\hline
\end{tabular}

Henceforth: $\mathrm{A}^{\star}=$ Excellent (81-100\%); $\mathrm{B}^{\star}=$ Very good (61-80\%); $\mathrm{C}^{\star}=$ Good (41-60\%); $\mathrm{D}^{\star}=$ Reasonable (21-40\%); $\mathrm{E}^{\star}=$ Poor $(0-20 \%)$. PPA: Multi-year plan. 
capacities, and the qualification, training, and set of policies aimed at promoting the human resources that operate the processes and generate outcomes.

The objective of this study is to demonstrate the situation of the state apparatus aimed at enforcing the management of forestry resources, given its attributions. From the disparities in the concentration of responses, with more than $60 \%$ of users indicating a bad situation, and the responses of the officers being between poor and reasonable, we can see the challenge that the State faces to strengthen the structure and capacity, for the implementation of the directives and actions of the state forest management (Table 3 ). This argument is reinforced by the existence of a strong correlation between the perceptions of users and officers regarding the forest management apparatus for the realization of the responsibilities of the state, presenting a Spearman correlation coefficient of $r_{p s}=0.85$ (Table 1 ).

The concentrations of citizen's services, physical and functional infrastructure, processes, and budgetary resources were the items that received a poor evaluation from both groups of respondents - officers and users - and, no less relevant, the clear definition of responsibilities, which indicates where the most severe deficiencies to be faced by public management are found (Table 3 ).
The deficiency pointed out by the research in all the elements of the forestry management structure is largely a consequence of the aforementioned gaps, that is, the duties of the institutional roles and the planning structure (Table 3 ).

The elements of the research clearly reflect what Husch (1987) and FAO (2010) postulated; that is, the lack of a well-defined policy within government makes it difficult to know if the structures of the institutions are properly scaled and equipped to apply the legislation and implement the programs.

\subsubsection{Human resource management}

This research item is related to the working system, qualification, training, and development of professional and individual careers, linked to organizational strategies. This relationship results in the motivation of professionals for institutional performance for forest management in the state. This item presents a concentration of responses distributed between "poor", "reasonable", and "good" evaluations, nearly equal for the perception of both samples, with a correlation of $r_{\text {sp }}=0.66$ (Table 1). As with the other items analyzed, the human resources dimension identifies challenges to be faced in order to strengthen state forestry management (Table 4).

Table 3. Results of the evaluation on the forest management structure, from the perspective of public officers and users.

\begin{tabular}{|c|c|c|c|c|c|c|c|c|c|c|}
\hline \multirow{3}{*}{ Forest management structure } & \multicolumn{10}{|c|}{ Evaluation (\%) } \\
\hline & \multicolumn{5}{|c|}{ Public officers } & \multicolumn{5}{|c|}{ Users } \\
\hline & $\mathbf{A}$ & B & C & $\mathbf{D}$ & $\mathbf{E}$ & A & B & C & D & $\mathbf{E}$ \\
\hline $\begin{array}{l}\text { Definition and implementation of forest } \\
\text { management tasks }\end{array}$ & & & 5 & 62 & 33 & & & 14 & 29 & 57 \\
\hline $\begin{array}{l}\text { Deconcentration - territorial distribution of } \\
\text { agencies and citizen services }\end{array}$ & & 5 & 14 & 5 & 76 & & & & 14 & 86 \\
\hline $\begin{array}{l}\text { Physical and instrumental infrastructure required } \\
\text { for forest management }\end{array}$ & & & 10 & 29 & 62 & & & 14 & 29 & 57 \\
\hline $\begin{array}{l}\text { Allocation of human resources according to the } \\
\text { needs of forest management }\end{array}$ & & & 29 & 38 & 33 & & & 14 & 14 & 71 \\
\hline Number of public officers in forest management & & & 38 & 29 & 33 & & & 14 & 14 & 71 \\
\hline Hierarchy and decision making & & & 24 & 29 & 48 & & & 14 & 43 & 43 \\
\hline $\begin{array}{l}\text { Internalization and democratization of forest } \\
\text { management }\end{array}$ & & & 14 & 38 & 48 & & & & 43 & 57 \\
\hline $\begin{array}{l}\text { Laws and regulations for the use and protection of } \\
\text { forest resources }\end{array}$ & & 10 & 24 & 33 & 33 & & & 14 & 43 & 43 \\
\hline Efficiency in the realization of processes & & & 19 & 29 & 52 & & & & 14 & 86 \\
\hline Budget resources & & & 10 & 29 & 62 & & & & 29 & 71 \\
\hline Average & & 1 & 19 & 32 & 48 & & & 9 & 27 & 64 \\
\hline
\end{tabular}

Henceforth: $A^{*}=$ Excellent (81-100\%); $B^{*}=$ Very good (61-80\%); $C^{*}=\operatorname{Good}(41-60 \%) ; D^{*}=$ Reasonable $(21-40 \%) ; E^{*}=$ Poor $(0-20 \%)$. 
Table 4. Results of the evaluation of human resources, from the perspective of public officers and users.

\begin{tabular}{|c|c|c|c|c|c|c|c|c|c|c|}
\hline \multirow{3}{*}{ Human resources } & \multicolumn{10}{|c|}{ Evaluation (\%) } \\
\hline & \multicolumn{5}{|c|}{ Public officers } & \multicolumn{5}{|c|}{ Users } \\
\hline & A & B & $\mathrm{C}$ & D & $\mathbf{E}$ & $\mathbf{A}$ & B & C & D & $\mathbf{E}$ \\
\hline Training of public officers & & 5 & 24 & 48 & 24 & & & 14 & 43 & 43 \\
\hline $\begin{array}{l}\text { Qualification of public officers for forest resource } \\
\text { management }\end{array}$ & & 5 & 33 & 52 & 10 & & & 14 & 57 & 29 \\
\hline Functional career of forest administration & 5 & 5 & 14 & 33 & 43 & & & 43 & 43 & 14 \\
\hline $\begin{array}{l}\text { Autonomy in the hiring and recruitment of human } \\
\text { resources }\end{array}$ & & 5 & 19 & 43 & 33 & & & 43 & 14 & 43 \\
\hline $\begin{array}{l}\text { Technical situation of training and attributions in } \\
\text { the area of forest resources }\end{array}$ & & 29 & 33 & 24 & 14 & & & 14 & 57 & 29 \\
\hline Quality of human resources policy & 5 & & 10 & 38 & 48 & & & 14 & 43 & 43 \\
\hline Quality of wage policy & 5 & & 10 & 29 & 57 & & & 14 & 29 & 57 \\
\hline Decision-making and teamwork & & 5 & 14 & 43 & 38 & & & & 43 & 57 \\
\hline Meritocractic promotion mechanism & & & & 43 & 57 & & & & 57 & 43 \\
\hline Motivational policy of employees & & & & 33 & 67 & & & & 29 & 71 \\
\hline Evaluation and performance policy & & 5 & & 33 & 62 & & & 14 & 29 & 57 \\
\hline Gender policy & & 10 & 33 & 24 & 33 & & & 14 & 29 & 57 \\
\hline Infrastructure suited to persons with special needs & & & 5 & 29 & 67 & & & & 14 & 86 \\
\hline Average & 1 & 5 & 15 & 36 & 42 & & & 14 & 37 & 48 \\
\hline
\end{tabular}

Henceforth: $\mathrm{A}^{*}=$ Excellent (81-100\%); $\mathrm{B}^{*}=$ Very good (61-80\%); $\mathrm{C}^{*}=$ Good (41-60\%); $\mathrm{D}^{*}=$ Reasonable (21-40\%); $\mathrm{E}^{*}=$ Poor (0-20\%).

The worst situations highlighted by the officers were the evaluation and performance of policy, the motivational practices, and the career and wage plans, which are directly related to the human resources situation. Motivation, evaluation, performance, decision-making, teamwork, and wage policies also generated impacts on the general public, according to the evaluation given by users and presented in Table 4.

The result of the research can be seen as a guide for state initiatives given the need to enforce forest management at a high level, since human resource management is determinant in the achievement of state initiatives in relation to the guidelines for forestry programs and in the application of its legislation.

\subsubsection{Management of administrative processes}

This part of the study is dedicated to organizational functioning, from the analysis of its physical, instrumental, and process structures and based on its legal attributions, according to its mission. The functioning of these elements and the interaction of all public institutions with civil society is a link between their respective organizational roles and the demands of society, converging, therefore, on the organizational identity of forest management.
The formation of an institutional identity related to the forestry area in the state still requires structuring before the society, given the poorly constituted institutional framework for this area in the governmental management structure (Table 5).

The conflict of responsibilities related to the forestry area in the administrative sphere was pointed out by both users and officers, with a correlation of $\mathrm{r}_{\mathrm{sp}}=0.77$ (Table 1) - a factor to be corrected as a basic issue to strengthen state forestry management (Table 5).

The inter-institutional relations and the transversality of forest management were the elements that presented a relative distribution of weight, from poor to very good, from both officers and users.

The apparatus for the implementation of forestry policy, such as the management structure, human resources, and administrative processes, is identified as deficient here - which was already expected due to the fragility of the planning structure. This institutional characteristic revealed by the research escapes the precept of the FAO (2010) that the institutional mission must be aligned with the objectives of the policy and an institutional arrangement scaled to fulfill its functions. 
Table 5. Results of the evaluation for administrative processes and structure, from the perspective of public officers and users.

\begin{tabular}{|c|c|c|c|c|c|c|c|c|c|c|}
\hline \multirow{3}{*}{ Administrative processes and structure } & \multicolumn{10}{|c|}{ Evaluation (\%) } \\
\hline & \multicolumn{5}{|c|}{ Public officers } & \multicolumn{5}{|c|}{ Users } \\
\hline & $\mathbf{A}$ & $\mathbf{B}$ & $\mathrm{C}$ & D & $\mathbf{E}$ & $\mathbf{A}$ & $\mathbf{B}$ & $\mathbf{C}$ & $\mathbf{D}$ & $\mathbf{E}$ \\
\hline Institutional identity & & 10 & 19 & 48 & 24 & & & 29 & 43 & 29 \\
\hline Institutional Mission of Forest Management & 5 & & 19 & 43 & 33 & & & & 86 & 14 \\
\hline $\begin{array}{l}\text { Definition and implementation of forest } \\
\text { management activities and routines }\end{array}$ & & 5 & 24 & 43 & 29 & & & 14 & 29 & 57 \\
\hline Conflict of duties with other agencies & 5 & & 10 & 19 & 67 & & & & 57 & 43 \\
\hline $\begin{array}{l}\text { Integration between legal duties and the } \\
\text { management model }\end{array}$ & 5 & & 5 & 62 & 29 & & & & 57 & 43 \\
\hline Interinstitutional relations & & & 57 & 24 & 19 & & 14 & 14 & 29 & 43 \\
\hline Transversality of forest management & & 5 & 19 & 38 & 38 & & & 29 & 43 & 29 \\
\hline Organizational structure of forest management & & & 14 & 52 & 33 & & & 29 & 14 & 57 \\
\hline $\begin{array}{l}\text { Decentralization -municipalization of forest } \\
\text { management }\end{array}$ & & & & 5 & 95 & & & & 29 & 71 \\
\hline Average & 2 & 2 & 19 & 37 & 41 & & 2 & 13 & 43 & 43 \\
\hline
\end{tabular}

Henceforth: $\mathrm{A}^{*}=$ Excellent (81-100\%); $\mathrm{B}^{*}=$ Very good (61-80\%); $\mathrm{C}^{*}=\operatorname{Good}(41-60 \%) ; \mathrm{D}^{*}=$ Reasonable (21-40\%); $\mathrm{E}^{*}=$ Poor $(0-20 \%)$.

\subsubsection{Control systems}

The control system involves the mechanisms and means of measuring and monitoring the service and satisfaction of users of the state system, in relation to the use and protection of forestry resources, besides showing the degree of satisfaction of the involved parties or highlighting the interaction of organizations with the external context.

The information system, which is essential for public planning and is indicative for the private sector, presents significant shortcomings in terms of internal and external control mechanisms in the perception of users (with an average of $71 \%$ in the poor and reasonable categories) and a dispersion of results between poor and good from the perspective of officers (Table 6). Nevertheless, there is a relationship between the perceptions of officers and users, with $r_{s p}=0.75$ (Table 1), in relation to the situation of the information system of the state forest management.

The structure and functionality of the information system, as well as its accessibility and availability to the user, are essential for the transparency and efficiency of forest management.

The information system is an essential instrument for governance. In this respect, governance and social interaction include the channels of interaction of the parties involved in the use and protection of forestry resources, exposing the degree of the relationship between the government structure and the groups related to the sector, such as unions, associations, and others.

Regarding customer service, users perceived greater shortfalls in this item than officers. However, statistically there is a correlation between both perceptions, of $r_{\text {sp }}=0.77$ (Table 1). Overall, more than $50 \%$ of users responded that the analyzed elements are generally poor, while less than $50 \%$ of officers considered them to be poor; the two views, however, were more heavily concentrated on the "poor" evaluation (Table 7).

Regarding citizen's services, users assigned the lowest level of satisfaction to the governance network, with $60 \%$ reporting a poor performance - a fact that distorts the $46 \%$ attributed by the officers (Table 7). Despite this difference, there is a correlation between the perception of both audiences, with $\mathrm{r}_{\mathrm{sp}}=0.75$ (Table 1). However, the change in this perception expressed by the users of the state system of forest management requires efforts to strengthen partnerships with society. This change aims to increase the participation of the social network related to the area, generating improvements in transparency and social participation in decision-making in the public management of forestry resources in the state.

The control system, which involves service and customer service, governance, and social interaction, followed the pattern of the planning and implementation results - a fact that can be seen as a cyclical process of 
Table 6. Results of the evaluation on the information system, from the perspective of public officers and users.

\begin{tabular}{|c|c|c|c|c|c|c|c|c|c|c|}
\hline \multirow{3}{*}{ Information system } & \multicolumn{10}{|c|}{ Evaluation (\%) } \\
\hline & \multicolumn{5}{|c|}{ Public officers } & \multicolumn{5}{|c|}{ Users } \\
\hline & $\mathbf{A}$ & B & C & D & $\mathbf{E}$ & $\mathbf{A}$ & B & C & $\mathbf{D}$ & $\mathbf{E}$ \\
\hline Technology and information structure - IT & & 5 & 19 & 33 & 43 & & & & 14 & 71 \\
\hline Technical capacity in IT & & 5 & 38 & 38 & 19 & & & & 29 & 71 \\
\hline Forest data and information system - SDIF & & 5 & 14 & 29 & 52 & & & & 29 & 71 \\
\hline Operational technical capacity of the SDIF & & 5 & 29 & 19 & 48 & & & & 43 & 57 \\
\hline $\begin{array}{l}\text { Data and information on forest use and } \\
\text { protection available on the Internet }\end{array}$ & & & 10 & 38 & 52 & & & & 14 & 86 \\
\hline $\begin{array}{l}\text { Use of IT tools and means in organizational } \\
\text { management }\end{array}$ & & 5 & 14 & 43 & 38 & & & & 29 & 71 \\
\hline Average & & 4 & 21 & 33 & 42 & & & & 29 & 71 \\
\hline
\end{tabular}

Henceforth: $\mathrm{A}^{\star}=$ Excellent (81-100\%); $\mathrm{B}^{\star}=$ Very good (61-80\%); $\mathrm{C}^{\star}=$ Good (41-60\%); $\mathrm{D}^{\star}=$ Reasonable $(21-40 \%) ; \mathrm{E}^{\star}=$ Poor $(0-20 \%)$.

Table 7. Results of the evaluation of public service and citizen services and governance network, from the perspective of public officers and users.

\begin{tabular}{|c|c|c|c|c|c|c|c|c|c|c|}
\hline \multirow{3}{*}{$\begin{array}{l}\text { Provision of service and citizen service and } \\
\text { governance networks }\end{array}$} & \multicolumn{10}{|c|}{ Evaluation (\%) } \\
\hline & \multicolumn{5}{|c|}{ Public officers } & \multicolumn{5}{|c|}{ Users } \\
\hline & $\mathbf{A}$ & B & $\mathrm{C}$ & D & $\mathbf{E}$ & $\mathbf{A}$ & B & C & D & $\mathbf{E}$ \\
\hline \multicolumn{11}{|l|}{ Provision of services and citizen service } \\
\hline Provision of service and citizen service & & 5 & 24 & 43 & 29 & & & 43 & 14 & 43 \\
\hline Citizen service policy & & 10 & 29 & 29 & 33 & & & 29 & 14 & 57 \\
\hline $\begin{array}{l}\text { Evaluation instrument for service provision } \\
\text { and citizen services }\end{array}$ & & & 14 & 29 & 57 & & & & 29 & 71 \\
\hline Citizen service training & & & & 48 & 52 & & & & 43 & 57 \\
\hline Citizen service infrastructure and channel & & & 5 & 43 & 52 & & & & 43 & 57 \\
\hline Average & & 3 & 14 & 38 & 45 & & & 14 & 29 & 57 \\
\hline \multicolumn{11}{|l|}{ Governance network } \\
\hline Policy on professional ethics & & 14 & 38 & 48 & & & & 14 & 14 & 71 \\
\hline Government transparency policy & 10 & 24 & 33 & 33 & & & & 14 & 29 & 57 \\
\hline Internal communication and relations policy & 5 & 19 & 33 & 43 & & & & & 43 & 57 \\
\hline External relations policy & 5 & 33 & 19 & 43 & & & & & 57 & 43 \\
\hline Participative management & 5 & 14 & 24 & 57 & & & & & 43 & 57 \\
\hline Partnerships with society & 5 & 14 & 29 & 52 & & & & & 29 & 71 \\
\hline Average & 5 & 20 & 29 & 46 & & & & 5 & 37 & 60 \\
\hline
\end{tabular}

Henceforth: $\mathrm{A}^{\star}=$ Excellent (81-100\%); $\mathrm{B}^{*}=$ Very good (61-80\%); $\mathrm{C}^{*}=\operatorname{Good}(41-60 \%) ; \mathrm{D}^{*}=$ Reasonable (21-40\%); $\mathrm{E}^{*}=$ Poor $(0-20 \%)$.

interdependence. For GesPública (Brasil, 2009), this is the mechanism by which stakeholders are involved in the planning, monitoring, and evaluation of public administration and in the implementation of policy and program initiatives, which in this case proves to be "precarious", as the results show.

\subsubsection{Organizational management and standardization}

This addresses the performance of the state, a reflection of the result of the leadership of state organizations regarding the functions outlined in the legislation, strategies and goals, processes, and persons. The elements of this item are focused on the effectiveness and discipline of the use and protection of forestry resources, according to the principles of public administration.

According to the research, for both perspectives - officers and users -, the performance of the state is deficient in relation to planning of organizational management and standardization of forests (Table 8), with the relationship between the views being $\mathrm{r}_{\mathrm{sp}}=0.79$, according to the Spearman correlation coefficient (Table 1). These indicators contribute to public actions 
Table 8. Results of the evaluation on organizational management and standardization and control, from the perspective of public officers and users.

\begin{tabular}{|c|c|c|c|c|c|c|c|c|c|c|}
\hline \multirow{3}{*}{$\begin{array}{l}\text { Organizational management and } \\
\text { standardization and control }\end{array}$} & \multicolumn{10}{|c|}{ Evaluation (\%) } \\
\hline & \multicolumn{5}{|c|}{ Public officers } & \multicolumn{5}{|c|}{ Users } \\
\hline & $\mathbf{A}$ & $\mathbf{B}$ & $\mathrm{C}$ & $\mathbf{D}$ & $\mathbf{E}$ & $\mathbf{A}$ & $\mathbf{B}$ & $\mathbf{C}$ & $\mathbf{D}$ & $\mathbf{E}$ \\
\hline Level of bureaucracy & & 5 & & 33 & 62 & & & & 29 & 71 \\
\hline $\begin{array}{l}\text { Integrated administrative process management } \\
\text { system }\end{array}$ & & & & 43 & 57 & & & & 57 & 43 \\
\hline Training of human resources for forest management & & & 33 & 38 & 29 & & & 14 & 29 & 57 \\
\hline Administrative memory & & 5 & 10 & 33 & 52 & & & 29 & 14 & 57 \\
\hline Values for the public forest service & & 10 & 5 & 38 & 48 & & & & 43 & 57 \\
\hline $\begin{array}{l}\text { Impact on forestry administration from law of } \\
\text { forest decentralization }\end{array}$ & & 10 & 5 & 45 & 40 & & & 14 & 43 & 43 \\
\hline $\begin{array}{l}\text { Legislation on the use and protection of forest } \\
\text { resources (clarity and implementation) }\end{array}$ & & 10 & 5 & 25 & 60 & & 14 & & 29 & 57 \\
\hline $\begin{array}{l}\text { Technical standardization of forest management } \\
\text { duties }\end{array}$ & & & 20 & 35 & 45 & & & 14 & 29 & 57 \\
\hline Process flow and standardization & & & 10 & 50 & 40 & & & 14 & 14 & 71 \\
\hline Agility in the processing of demands & & & & 35 & 65 & & & 14 & & 86 \\
\hline Average & & 4 & 9 & 38 & 50 & & 1 & 10 & 29 & 60 \\
\hline
\end{tabular}

Henceforth: $A^{*}=$ Excellent (81-100\%); $B^{*}=$ Very good (61-80\%); $C^{*}=$ Good (41-60\%); $\mathrm{D}^{*}=$ Reasonable (21-40\%); E* = Poor (0-20\%).

in directing efforts toward adjusting forest management structures for a clear design of the "rules of the game", which is necessary for economic and social agents.

The low impact of the implementation process of decentralization of forest management, from the perspective of users and officers, set by article 83 , of Law 11,284/2006 and consolidated by Complementary Law 140/2011, indicates the need for reconstruction of the forestry policy.

This stage of the research reveals how all essential elements for the proper functioning of the organizational management, including standardization, is perceived by society, which classified it as "reasonable" and "poor". From the perspective of GesPública (Brasil, 2009), this part has values for the stakeholders, since decision-making, as well as implementation, is based on the performance analysis and measurements and on available information.

In this study, the elements of the excellence model for public management outlined by Lima (2007) were presented as a chain of interactions and interdependence between the organizational management elements and the external environment. This behavior was based on the disequilibrium identified in the institutional responsibilities, followed by planning, and, from there, it caused a cascade effect on the flow of the model, thus making it a systemic process.
The analysis of forest management, in the State of Amapá, in turn, explains the perception of the diverse "actors", represented by all organizations of producers and consumers of forest products and services, including universities, research institutions, non-governmental organizations, public officers linked to forest management, and related sectors, such as agriculture, mining, and others. We highlight that the responses given by these diverse actors affected by the forest policy, did not differ statistically from the vision of public officers dedicated to forest management.

\section{CONCLUSION}

The distribution of forest management in the diverse institutions generates, on the one hand, precariousness and a relative lack of institutional attention for users and society at large and, on the other hand, a lack of institutional identity as well as internal conflicts in the agendas of different governmental agencies, in terms of the forestry area.

Regarding organizational management, we can conclude that it is deficient. During the research, we observed that the correlation between the internal and external public perceptions regarding the organizational system, involving the planning, implementation, and control of forest policy is statistically significant, indicating a significant deficiency of state forest management. 
The study also showed the existence of conflicts of attributions in the realization of the State forestry administration, both within the sphere of formulation and in the implementation of forestry management between the four institutions (SDR, SEMA, IEF, and IMAP) responsible for the topic of "forests" in the State.

Thus, the research results allow us to conclude that the state system responsible for the management of forestry resources requires strengthening to arbitrate the pressures stemming from diverse interests, thus fulfilling its role. In addition, the forest coverage needs to be managed to promote the well-being of its populations and to transform the opportunity cost favorable to forestry maintenance given the alternative use of soil for large-scale grain production, - a situation that has expanded in the region given the ease off shore logistics.

\section{ACKNOWLEDGEMENTS}

Governo do Amapá, Instituto Estadual de Florestas do Estado do Amapá - IEF, Government of Amapá, State Forest Institute of Amapá - IEF.

\section{SUBMISSION STATUS}

Received: 10 feb., 2017

Accepted: 31 aug., 2017

\section{CORRESPONDENCE TO}

\section{José das Dores de Sá Rocha}

Departamento de Engenharia Florestal, Universidade Federal de Rondônia, Av. Curitiba, 5324, Planalto, CEP 76940-000, Rolim de Moura, RO, Brasil

e-mail: josedesa@unir.br

\section{FINANCIAL SUPPORT}

Governo do Estado do Amapá.

\section{REFERENCES}

Becker BK. Revisão das políticas de ocupação amazônica: é possível identificar modelos para projetar cenários? Parcerias estratégicas, v. 12, p. 135-159, 2001.

Becker BK. Problematizando os serviços ambientais para o desenvolvimento da Amazônia: uma interpretação geográfica. In Becker BK, Costa FA, Costa WM. Um projeto para a Amazônia no século 21: desafios e contribuições. Vol. 1. Brasília: CGEE, 2009. p. 87-120.

Becker BK. Papel do Estado brasileiro no desenvolvimento da Amazônia. In: Val AL, Santos GM, editores. Grupo de estudos estratégicos amazônicos. Manaus: GEEA; 2011. p. 105-136. (Caderno de Debates, no. 4).

Bernâsen, C. A. F., Machado, A. J. L. Os estilos de administração em prefeituras do rio grande do sul: um teste da teoria de Rensis Likert. Revista de Administração de Empresa 1974; 14(4): 29-48.

Brasil. Ministério do Planejamento, Orçamento e Gestão. Subsecretaria de Planejamento, Orçamento e Gestão. Programa Nacional de Gestão Pública e Desburocratização - GesPública. Prêmio Nacional da Gestão Pública - PQGF. Fórum Nacional 2008/2009. Brasília: MP: SEGES; 2009. 56 p. (Documento de Referência, no. 1).

Costa WM, Costa FA. Estruturas, dinanicas e perspectivas. In: Becker BK, Costa WM. Um projeto para a Amazônia no século 21: desafios e contribuições. Vol. 1. Brasília: CGEE; 2009. p. 139-387.

Cunha LMA. Modelos Rasch e Escalas de Likerte Thurstone na medição de atitudes [dissertação]. Lisboa: Departamento de Estatística e Investigação Operacional, Faculdade de Ciências, Universidade de Lisboa; 2007. 78 p.

Forestry Department Technical Meeting - FAO. Crosssectoral policy impacts between forestry and other sectors. Rome: FAO; 2002. (Relatório Técnico)

Forestry Department Technical Meeting - FAO. Impactos inter-sectoriales de laspoliticas forestales y de otros sectores. Roma: FAO; 2005.50 p. (Estúdio de Montes; no. 142).

Forestry Department Technical Meeting - FAO. Elaboración de una política forestal eficaz: una guía. [online]. Roma: FAO; 2010. [cited 2012 Aug 06]. Available from: http:// www.fao.org/docrep/009/a0645s/a0645s00.htm.

Husch B. Guidelines for forest policy formulation. Roma: FAO; 1987. 88 p. (FAO Forestry Paper; no. 81).

Instituto Brasileiro de Geografia e Estatística - IBGE. Banco de Tabelas Estatísticas - SIDRA. Censo Agropecuário [online]. Brasília: IBGE; 2014. [cited 2014 Oct 30]. Available from: http://www.sidra.ibge.gov.br/

Instituto Nacional de Pesquisas Espaciais - INPE. Resultado final do PRODES 2013 [online]. 2014. Available from: http://www.inpe.br/. [cited 2014 Sep 10].

Lima PDB. A excelência em gestão pública: a trajetória e a estratégia do gespública. Rio de Janeiro: Qalitymark, 2007. 227p.

Luchesa CT. Anotações de estatística: finanças empresarial. Curitiba; 2013. 61 p. (Relatório Técnico).

Nepstad D, McGrath D, Stickler C, Alencar A, Azevedo A, Swette B et al. Slowing Amazon deforestation through 
public policy and interventions in beef and soy supply chains. Science 2014; 344(6188): 1118-1123. http://dx.doi. org/10.1126/science.1248525. PMid:24904156.

Pereira D, Santos D, Vedoveto M, Guimarães J, Veríssimo A. Fatos florestais da Amazônia 2010. Belém: Imazon, 2010.

R Core Team. R: A language and environment for statistical computing. R Foundation for Statistical Computing [online]. Vienna: The R Foundation; 2013. [cited 2014 Jan 22]. Available from: http://www.R-project.org/

Saraph JV, Benson PG, Schroeder RG. An instrument for measuring the critical factors of quality management. Decision Sciences 1989; 20(4): 810-829. http://dx.doi. org/10.1111/j.1540-5915.1989.tb01421.x.
Siegel S. Estatística não-paramétrica para as ciências do comportamento. Farias AA, tradutor. São Paulo: McGrawHill; 1975.

Tucker CM, Ostrom E. Pesquisa multidisciplinar relacionando instituições e transformações florestais. In Moran E, Ostrom E. Ecossistemas florestais: interação homem-ambiente. Alves DS, Batistella M, tradutor. São Paulo: Edusp: Senac; 2009.

World Resources Institute - WRI, Instituto do Homem e Meio Ambiente da Amazonia - Imazon, Instituto Centro de Vida - ICV. Governance of forests initiative: indicator framework (version 1). [online]. Washington: 2009. [cited 2013 Jan 3] (Relatório Técnico). Available from: http:// www.wri.org/publication/governance-of-forests-initiativeindicator-framework 